\title{
CORRIGENDUM
}

\section{Bidwill of Wide Bay: A Botanist Cut Short - CORRIGENDUM}

\section{Stuart Read}

doi: 10.1017/qre.2012.7, Published by Cambridge University Press, 3 September 2012

In order to correct some inaccuracies and omissions from Read's (2012) article, published in the Queensland Review, Volume 19, Issue 1, the author would like to make the following amendments:

On page 76 , the term ' $S$. tetraptera' should appear without a capital ' $T$ '.

It is acknowledged that Bidwill did not name Earina autumnalis, and therefore on pages 76-77, the following sentence should read:

Bidwill took to London the tiny scented Easter orchid Earina autumnalis which he found near Lake Taupo, and was first to collect the herb Scutellaria novaezelandicae on the Waimea plain outside Nelson.

On page 77 , the name of Tucker's company was given incorrectly. The sentence should read:

Tucker started business again in 1848 on George Street, and the company survives today as Tucker Seabrook (Aust.) P/L.

To correct a couple of omissions on page 78 , the following bullet point should read:

Rosa chinensis 'Imogen' (Camden Park, 1845) is a cluster-flowered hybrid China rose, bred at Camden Park. Macarthur called it a 'new hybrid, pure white' in an 1845 letter to John Bailey, Adelaide nurseryman.

On pages 79 and 85, E. 'Camdeni' and Erythrina $x$ bidwillii 'Camdeni' should read E. $x$ 'Camdeni' and Erythrina $x$ bidwillii 'Camdeni' respectively, and E. $x$ bidwillii 'Blakei' should read Erythrina $x$ bidwillii 'Blakei'. 
On page 79 , the correct term 'Crinum $x$ Amaryllis' should replace ' $\mathrm{x}$ Crinum Amaryllis'.

On page 82, 'Ferdinand Mueller' should replace 'Baron Ferdinand von Mueller' as he was not given this title until a later date.

On page 85 , 'species' should replace the incorrectly spelt 'specie'.

On page 85 , the correct term 'H.x 'Sydneyi' should replace ' $x$ Sydneyi'.

The author would like to add the following text to the acknowledgements on page 86:

This text is very largely taken from the published writings of Professor David Mabberley who has consented to many parts of them being closely reproduced here. With particular thanks to: Keith Jorgensen, ex-Maryborough resident for his generosity and many leads; David Mabberley, Director of the Royal Botanic Gardens, Sydney; Colin Mills for Hortus Camdenensis with its Bidwill mentions and Professor Richard Clough for his research on Bidwill's plant hybridisation.

On page 86 , the following text should be added to endnote 2 :

(or another of William Macarthur's contacts www.hortuscamden.com/entry))

On page 87 , the correct page reference for the following citation in endnote 9 is 546:

Mabberley, 'Plant Introduction and Hybridisation': 546 also cites a letter by H. Bidwill ...

On page 88 , the full citation in endnote 24 should be:

Olde and Marriot, The Grevillea Book, vol 2, 49;

On page 88 , the correct publication date for the following citation in endnote 28 is 2002:

Clough, Richard, 'Bidwill, John Carne', The Oxford Companion to Australian Gardens, eds Richard Aitken and Michael Looker (Oxford: Oxford University Press \& AGHS, 2002): 90-1.

\section{Reference}

Stuart Read (2012). Bidwill of Wide Bay: A Botanist Cut Short. Queensland Review, 19, pp 75-88 doi:10.1017/qre.2012.7 